\title{
CFD Analysis on Francis Turbine to Analyse Erosion Wear Due to Sediment Flow
}

\author{
Uttam Singh Yadav \\ M. Tech Scholar \\ Truba Institute of Engineering \& \\ Information Technology \\ Bhopal, M.P., India \\ yadavuttam60@gmail.com
}

\author{
Shravan Vishwakarma \\ Assistance Professor \\ Truba Institute of Engineering \& \\ Information Technology \\ Bhopal, M.P., India
}

\author{
Jitendra Mishra \\ Assistance Professor \\ Truba Institute of Engineering \& \\ Information Technology \\ Bhopal, M.P., India
}

\begin{abstract}
In present work Computational fluid dynamics analysis based erosion wear prediction is performed for Francis turbine components, especially the runner. For the geometrical parameters, Francis turbine model with steady state condition and viscous flow turbulence SST model using ANSYS Fluent. The erosion effect on all the three component such as spiral casing, runner \& draft tube has been studied for different concentration of sand particles from $1 \%-6 \%$. For each of those concentration the effect of variation in size has been studied for different sizes $10 \mu \mathrm{m}-80 \mu \mathrm{m}$. Further the effect of total erosion was also analyzed for different particle size. Erosion damage is found close to the upper and lower portions of the leading edge of the stay vane. some erosion spots at guide vane on the blade pressure side where suction side has minimum erosion. Maximum erosion damage observed on runner especially at the middle of the blade. The draft tube situated closer to runner having highest velocity due to high absolute velocity of water coming out from the runner does not produce any serious erosion effect. Results shows that erosion rate is maximum on runner at particle size $80 \mu \mathrm{m}$ for all sand concentration $1 \%$ to $6 \%$ and minimum at $30 \mu \mathrm{m}$. Thus, 30 $\mu \mathrm{m}$ is the optimum size of sand particles for the erosion.
\end{abstract}

Keywords: Erosion wear, sedimentation, particles size, turbine, runner, CFD etc.

\section{INTRODUCTION}

Sediment erosion is caused by the dynamic action of sediment, which flows with the water hitting a solid surface and creating surface wear on the hydraulic turbine components such as the housing, channel, and suction pipe. This wear not only reduces the turbine's efficiency and life but also causes operational and maintenance problems, which ultimately lead to economic losses. The high concentration of sediment combined with a high percentage of quartz in the water causes severe damage to the components of the hydraulic turbine. The intensity of the erosion depends on the type of sediment and its properties such as shape, size, hardness, concentration, etc. Hydraulic turbine design and operating conditions such as flow, height, velocity, velocity, acceleration, turbulence, angle of attack, etc.

Minimizing sediment erosion problems requires a multidisciplinary approach. Further research and development is needed to examine the relationship between particle motion and erosion in a turbine and to determine the operational strategy for turbine operation.

The erosion process is highly dependent on the particle size, shape, concentration, and operating conditions of the turbine. The reduction of erosion is associated not only with the reduction of particle velocity but also with the reduction of flow separation, which further depends on the shape, size, and concentration of the particle. A significant reduction in the erosion rate can be achieved by running the turbine at its best efficiency.

\section{LITERATURE REVIEW}

R.D. Aponte et al. [1] Erosive wear is a major problem both economically and technically in the running water turbines of medium and small Francis turbines. The methodology uses computational fluid dynamics (CFD) and optimization techniques such as: which at the same time takes into account the erosive wear of hard particles, cavitation damage and efficiency. It was found that the new geometries of the turbine components analyzed allow a reduction in the wear rate of up to $73 \%$ and maintain an efficiency close to the original value over the entire operating range.

Gyanendra Tiwari et al. [2] The main goal of the work is to critically review various calculation methods to achieve various hydraulic design goals and performance evaluation of hydraulic turbines. To this end, various objectives of the computer studies of water turbines are discussed in detail such as the derivation of the performance characteristics, the analysis of various unstable phenomena, the prediction and analysis of cavitation and the determination of the various losses.

Gyanendra Tiwari et al. [3] Analyzes the effects of the cavitation phenomenon in different operating states of a Francis turbine prototype with a capacity of $3 \mathrm{MW}$ with the CFD code ANSYS CFX. Detailed flux range analyzes are performed for partial loads of $60 \%$ and $80 \%$, full load, and overload of $120 \%$ with and without cavitation. A critical 
examination of the variation of the different flow parameters for cases with and without cavitation is one of the highlights of the work.

S. Gautam et al. [4] this article presents a case study of a specific low-speed Francis turbine power plant in India that is severely affected by sediment erosion problems. A digital flow analysis is performed inside the turbine to investigate the causes of various erosion patterns in the turbine components. The results of the CFD are compared with the actual erosion of the turbines.

\section{OBJECTIVE}

There are following objective are to be expected from the present work:

1. To study the theoretical concepts of wear/Erosion in Francis turbine at various components such as casing, runner and draft tube.

2. To perform the fluid flow analysis on Francis turbine with erode particles at various parameters sand concentration, particles size and shape factor.

3. To identify critical zones of erosion and proposed optimizes operating conditions based upon particle size and sand concentration.

\section{Methodology}

The mechanisms of erosive wear are not constant, but are controlled by the angle of impact of a particle, its speed, size and phase of the material of which the particles are made. The angle of impact is the angle between the eroded surface and the trajectory of the particle just before impact. A small angle of attack promotes wear-like wear processes, as particles tend to migrate to the worn surface after impact. A high angle of incidence causes wear mechanisms typical of erosion.

Algorithm used for Computational fluid dynamics analysis

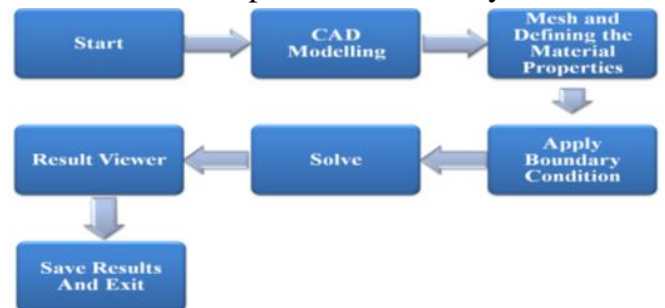

Fig. 1: Algorithm used for Computational fluid dynamics analysis

A. Computational fluid dynamics Analysis of Francis turbine In the present work three dimensional CAD geometric of Francis turbine which includes casing, stay vanes, guide vanes, runner and draft tube have been created using approximate dimension for turbulent flow analysis in Francis turbine. for that some important parameters have been taken from the base paper as mentioned in table-1. For the creation of CAD model ANSYS design modular have been used. The details of important parameters of the turbine are given in Table: 1. [Adnan Aslam Noon 2017].

\begin{tabular}{|l|c|}
\hline Parameter & Dimensional Value \\
\hline Head $[\mathrm{m}]$ & 97 or 3.1 for simulation \\
\hline Discharge $\left[\mathrm{m}^{3} / \mathrm{Sec}\right]$ & 979 or 6.31 for simulation \\
\hline Power $[\mathrm{MW}]$ & 175 or 0.035 for simulation \\
\hline Runner Diameter $[\mathrm{m}]$ & 4.77 or 0.94 for simulation \\
\hline Runner Speed $[\mathrm{RPM}]$ & 136 or 121.6 for simulation \\
\hline No. of Blades & 13 \\
\hline No. of guide vane & 22 \\
\hline No. of Stay vane & 10 \\
\hline
\end{tabular}

\section{B. CAD Geometry of Spiral Casing:}

The spiral casing shown below consists of an inlet section followed by gradually decreasing cross-sectional area which leads the flow to the stay vane inlet. 3D views of casing are shown in figure no. 2 .

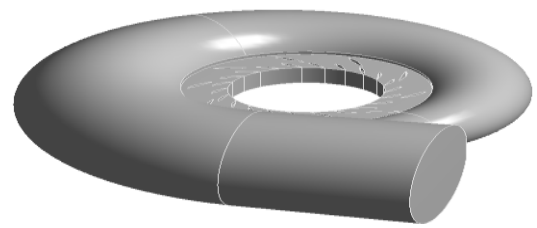

Fig. 2: CAD Model of Spiral Casing

\section{CAD Geometry of Runner:}

The runner domain assembly of 13 runner blades fixed between two surfaces hub and shroud. The runner blades are taken as solid body. The inlet of the runner is connected to the distributor outlet and outlet of the runner is connected to the draft tube inlet through interface. Separate three dimensional views of runner are shown in figure 3 .

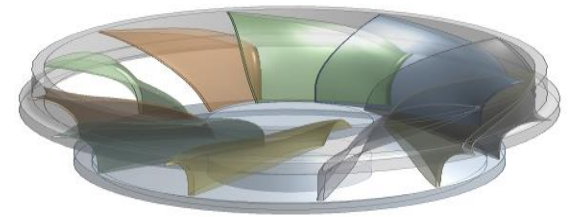

Fig. 3: CAD Model of Runner

D. CAD Geometry of Draft tube:

The inlet of the draft tube is connected to the outlet of the runner domain thorough interface. Three dimensional views of draft tube are shown in Fig.4.

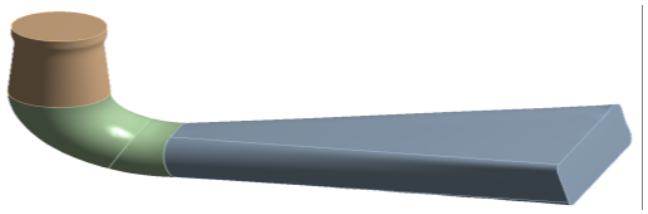

Fig. 4: CAD Model of Draft Tube

E. CAD Geometry of complete assembled Francis Turbine:

All the three domains are connected through proper interfaces to complete the turbine space for analysis the assembled complete turbine shown above. 3D views of assembled Francis Turbine are shown in Figure 5. 


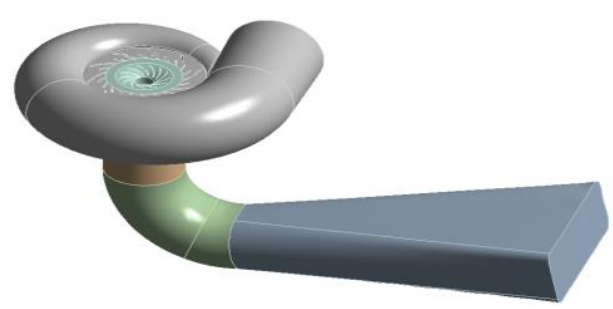

Fig. 5: CAD Model of assembled Francis Turbine F. Meshing of Spiral Casing:

Meshing is a critical operation in finite element analysis in which CAD geometry is divided into large numbers of small pieces. The small pieces are called mesh. The mesh created for casing in this work is shown in figure no. 6. Total number of nodes: 6343422 and Total number of Elements: 4654007 at element size $5 \mathrm{~mm}$ having tetrahedral elements.

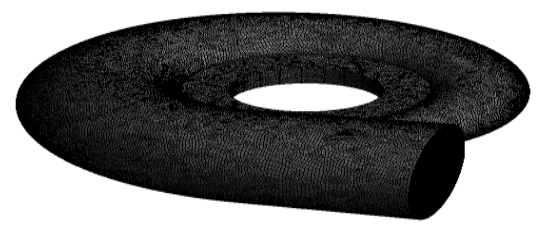

Fig. 6: Meshing of spiral casing

\section{G. Meshing of runner:}

The mesh created for runner in this work is shown in fig. 7 Total number of nodes: 798262 and Total number of Elements: 579231 at element size $5 \mathrm{~mm}$ having tetrahedral elements on hub and shroud and the turbine blade having hexahedral element.

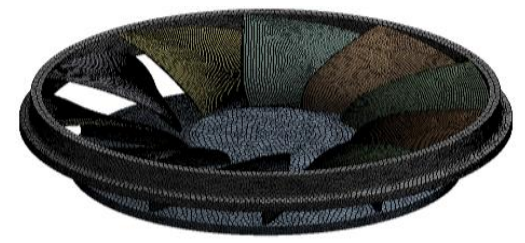

Fig. 7: Meshing of runner

\section{H. Meshing of draft tube:}

The mesh created for draft tube in this work is shown in figure No. 4.8 Total number of nodes: 1579477 and Total number of Elements: 630503 at element size $10 \mathrm{~mm}$ having tetrahedral and hexahedral element.

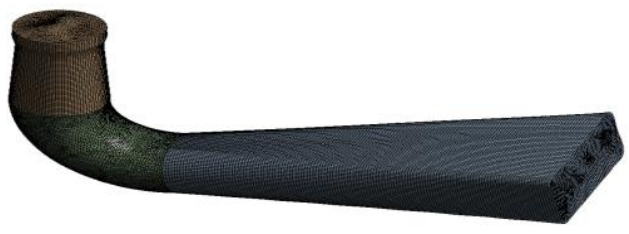

Fig. 8: Meshing of draft tube

I. Meshing of complete assembly of Francis turbine

Total number of nodes: 8721161 and Total number of Elements: 5863741 at element size $5 \mathrm{~mm} \& 10 \mathrm{~mm}$ having tetrahedral and hexahedral element. The mesh created for assembled Francis turbine in this work is shown in fig. 9

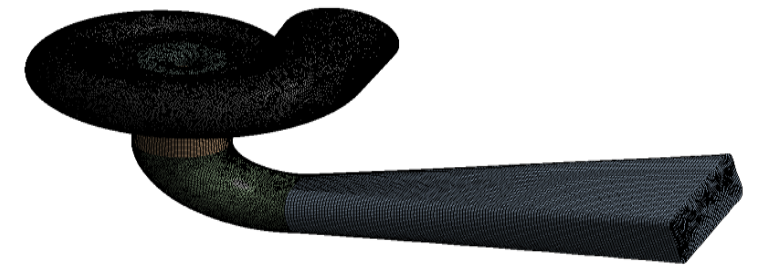

Fig. 9: Meshing of complete assembly of Francis turbine Table 2: Mesh Data for complete assembly of Francis turbine

\begin{tabular}{ccc}
\hline Parts of Francis turbine & No. of nodes & No. of elements \\
\hline Casing & 6343422 & 4654007 \\
Runner & 798262 & 579231 \\
Draft Tube & 1579477 & 630503 \\
\hline Complete assembly & 8721161 & 5863741 \\
\hline
\end{tabular}

J. Governing Equations

Conservation of mass or continuity equation:

$$
\nabla \cdot\left(\alpha_{t} \cdot \rho_{t} \cdot V_{t}\right)=0
$$

Where

$$
\begin{aligned}
& \alpha_{t}=\text { Volumetric concentration } \\
& \rho_{t}=\text { Density } \\
& V_{t}=\text { Velocities } \\
& \mathrm{T}=\text { either solid phase (s) or fluid phase (f) }
\end{aligned}
$$

SST model for multiphase flow:

$$
\mu_{T}^{m}=\frac{\rho^{m} \cdot a_{1} \cdot k^{m}}{\max \cdot\left(a_{1} \cdot \omega^{m}, S^{m} \cdot F_{2}\right)}
$$

Where

$$
\begin{aligned}
& \rho=\text { Density } \\
& K=\text { kinetic energy } \\
& \omega=\text { Turbulent frequency } \\
& F_{2}=\text { Blending function } \\
& \mu_{T}=\text { Turbulent viscosity } \\
& S=\text { Shear stress } \\
& m=\text { Mixture of sediments } \\
& a_{1}=\text { Coefficient which determines the fraction of } \\
& \text { fluid or solid present. }
\end{aligned}
$$

Erosion modeling:

Erosion is found to vary with impact angle and velocity according to the relationship

$$
E=k V_{p}^{n} \cdot f(\gamma)
$$

Where

$k=$ Constant depends on fluid properties, like density, viscosity, slurry temperature etc.

$V_{p}=$ Impact velocity

$n=$ velocity exponent, which is dependent on material of the eroded surface, generally in the range 2.3 to 2.5 for $f(\gamma)=$ Function of impact angle If the $n=2$ : then

$$
E=k V_{p}^{2} \cdot f(\gamma)
$$

$f(\gamma)$ Can be found by using following relation

$$
\begin{gathered}
f(\gamma)=\frac{1}{3} \cos ^{2}(\gamma), \text { When } \gamma>18.4^{\circ} \\
f(\gamma)=\sin (2 \gamma)-3 \sin ^{2}(\gamma), \quad \text { When } \gamma<18.4^{\circ}
\end{gathered}
$$

Sediment particles size and shape:

Alertson shape factor is used to calculate the values of shape factor, $\Psi_{A}$ 
Where

$$
\Psi_{A}=\frac{c}{\sqrt{(a \cdot b)}}
$$

$$
\begin{aligned}
& \Psi_{A}=\text { Albertson shape factor } \\
& a=\text { Longest side } \\
& b=\text { Dimension in third axis and } \\
& c=\text { shortest side }
\end{aligned}
$$

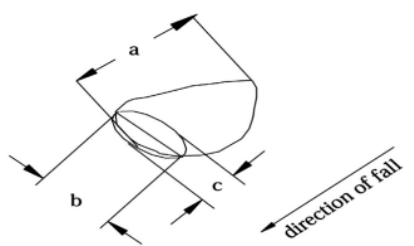

Fig. 10: The axes of an irregular shape particle

Sediment particles concentration:

It has been observed that the sediments concentration is much higher during the monsoon season as compared with other season.

Table: 3 Sediment particles concentration as a function of water head [Adnan Aslam Noon 2017]

\begin{tabular}{|l|l|l|}
\hline Head & Months & Concentration [PPM] \\
\hline Low & November -March & $5000-10000$ \\
\hline Medium & April - June & $10000-30000$ \\
\hline High & July - October & $30000-60000$ \\
\hline
\end{tabular}

K. Drop in runner efficiency:

The operational period of one monsoon season, the average loss of efficiency recorded at Best Efficiency Point (BEP) is about 4\%. [Adnan Aslam Noon 2017]

Where

$$
\eta=\frac{P}{\rho \cdot g \cdot Q \cdot h_{T}}
$$

$$
\begin{aligned}
& \mathrm{P}=\mathrm{T} . \omega \text { Actual power produced } \\
& \rho=\text { Water density } \\
& \mathrm{g}=\text { gravity } \\
& \mathrm{Q}=\text { Volume flow rate } \\
& \mathrm{h}_{\mathrm{T}}=\text { Available turbine head. }
\end{aligned}
$$

Boundary Conditions:

The boundary conditions are applied at inlet and outlet of a flow domain and the wall enclosing the domain. The following boundary conditions are given in the present simulations.

1. Select viscous model for turbulent flow as transient SST for reasonable accuracy for turbines.

2. Discrete Phase on for erosion analysis:

- Enable interaction with continuous phase and set maximum no. of steps as 1500 .

- In physical model option enable Erosion/Accretion for Erosion analysis.

- inject particles as sand with dimension as given in below table 4.06

Table 4.6 Inject particles as sand with dimension

\begin{tabular}{l|l} 
Parameters & Value
\end{tabular}

\begin{tabular}{|l|l|}
\hline $\begin{array}{l}\text { Sediments particle size dp } \\
\text { [microns] }\end{array}$ & $10,20,30,40,50,60,70,80$ \\
\hline Sediments particle shape factor $\Psi_{\mathrm{A}}$ & $0.2,0.3,0.4,0.5,0.6,0.7,0.8,0.9$ \\
\hline Sediments concentration $\mathrm{C}_{\mathrm{w}}[\%]$ & $0.5,1,2,3,4,5,6$ \\
\hline
\end{tabular}

Average shape factor $\Psi_{\mathrm{A}}$ taken as 0.65 as described in Adnan Aslam Noon et al. 2017.

3. Inlet boundary condition: The mass flow rate of $6.31 \mathrm{~m}^{3} / \mathrm{s}$ is taken as inlet of casing of the Francis turbine. Flow occurring throughout the geometry is subsonic. Flow direction is normal to the inlet boundary and turbulence is set at medium (intensity $=5 \%$ ).

4. Outlet boundary condition: At outlet of draft tube atmospheric pressure is taken as outlet boundary condition.

5. Walls: The walls of the Francis turbine components of domains are taken as smooth with no slip condition.

6. Fluent Solver is used to perform computational fluid dynamics analysis.

\section{RESULTS}

In the present work detailed analysis in a Francis turbine casing, runner and draft tube due to the flow of sand particles has been studied for turbulent flow as transient SST model at mass flow rate where outlet of draft tube atmospheric pressure is taken as outlet boundary condition. The erosion effect on all the three component (spiral casing, runner \& draft tube) has been studied for different concentration of sand particles- $1 \%$, $2 \%, 3 \%, 4 \%, 5 \%$ and $6 \%$. For each of those concentration the effect of variation in size has been studied for different sizes $(10,20,30,40,50,60,70 \& 80 \mu \mathrm{m})$. Further the effect of total erosion was also analysed for different particle size. The erosion rate is calculated in $\mathrm{kg} / \mathrm{m} 2-\mathrm{s}$, These data were generated using ANSYS fluent under the different operating conditions.

Validation of work

The main objective of present work to analyzed the effect of erosion rate on Francis turbine at different concentration of sand particles $(1 \%, 2 \%, 3 \%, 4 \%, 5 \%$ and $6 \%)$ and different sizes of sand particles $(10,20,30,40,50,60,70 \& 80 \mu \mathrm{m})$. Adnan Aslam Noon \& Man-Hoe Kim (2017) worked on "Erosion wear on Francis turbine components due to sediment flow" using computational fluid dynamics analysis at different size of sand particles (only at 20,40\&80 $\mu \mathrm{m}$ ) to find out the Erosion wear on Francis turbine components. For the validation purpose two graphs of have been compared as shown in fig. 11 (a) \& (b). 


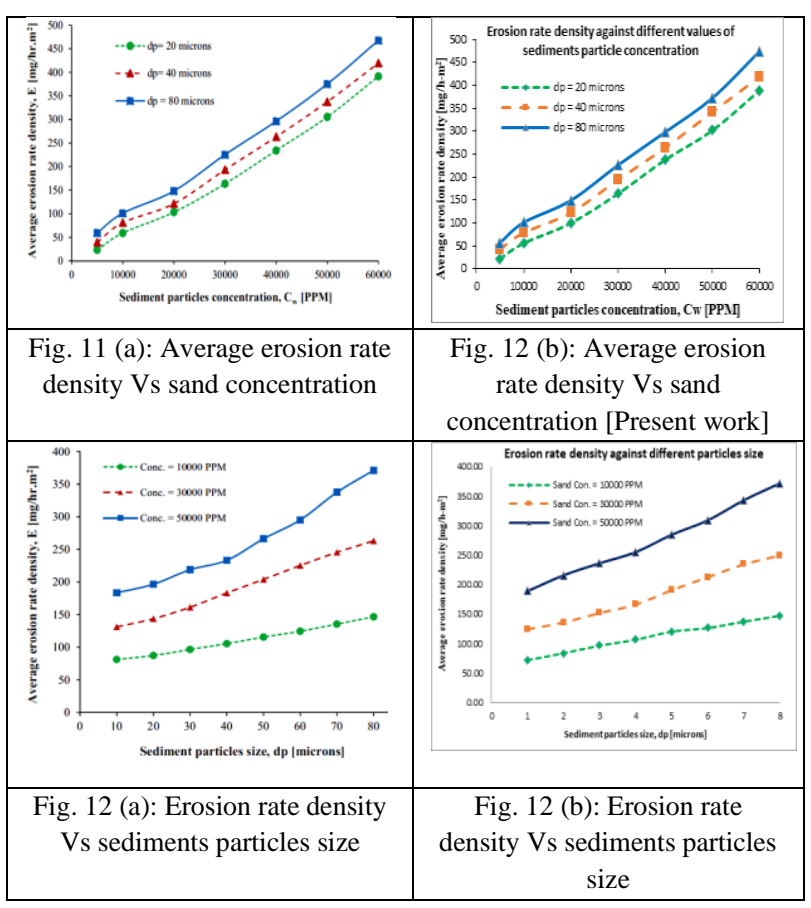

From the above validation it also has been observed that Adnan Aslam Noon worked on only three particle size such as $20,40 \& 80$ microns and did not show the location of erosion rate on Francis turbine components, so in present work perform CFD analysis performed to find erosion rate for different concentration ( 10000 - 60000 PPM with interval of 10000PPM ) different particle sizes $(10,20,30,40,50,60,70$ \& $80 \mu \mathrm{m})$.

Sand Erosion rate analysis at 10000 PPM sediments concentration:

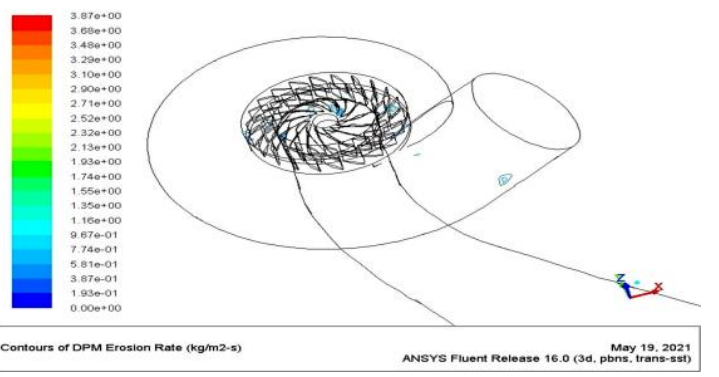

Figure 13: Sand Erosion rate at $1 \%$ Sediments concentration for $10 \mu \mathrm{m}$ size

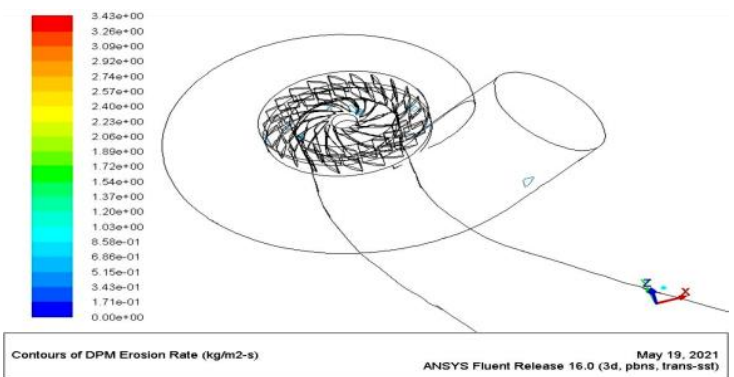

Fig. 14: Sand Erosion rate at $1 \%$ Sediments concentration for $20 \mu \mathrm{m}$ size

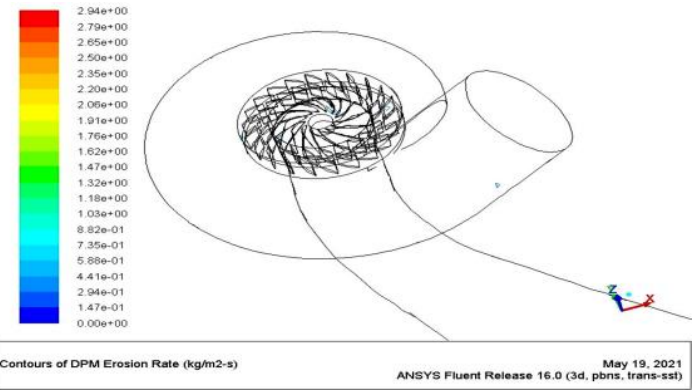

Fig. 15: Sand Erosion rate at $1 \%$ Sediments concentration for $30 \mu \mathrm{m}$ size

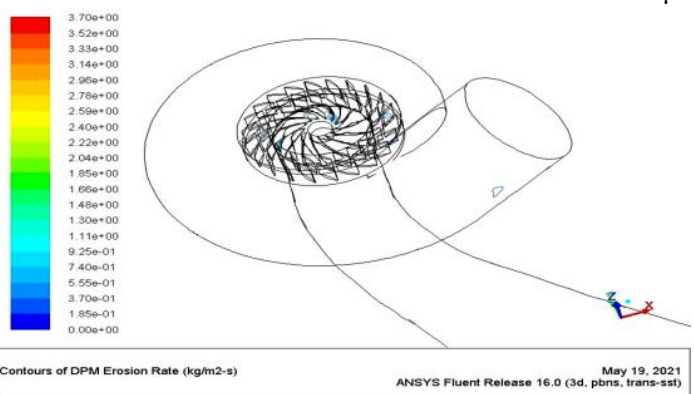

Fig. 16: Sand Erosion rate at $1 \%$ Sediments concentration for $40 \mu \mathrm{m}$ size

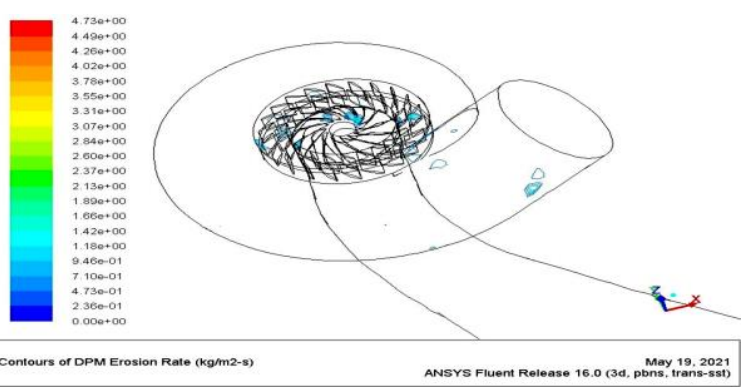

Fig. 17: Sand Erosion rate at $1 \%$ Sediments concentration for $50 \mu \mathrm{m}$ size

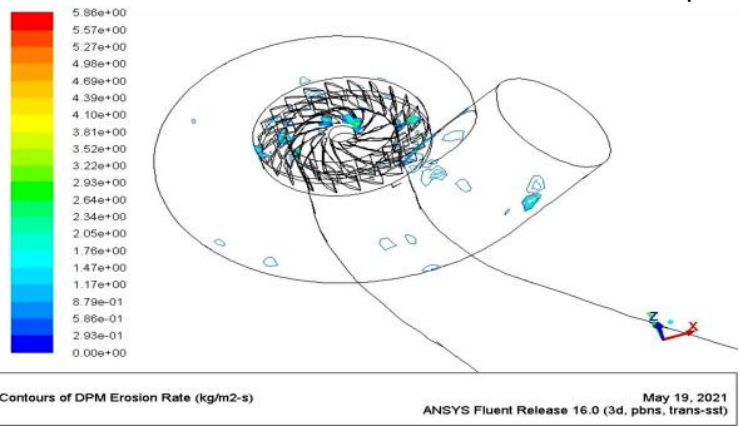

Fig. 18: Sand Erosion rate at $1 \%$ Sediments concentration for $60 \mu \mathrm{m}$ size

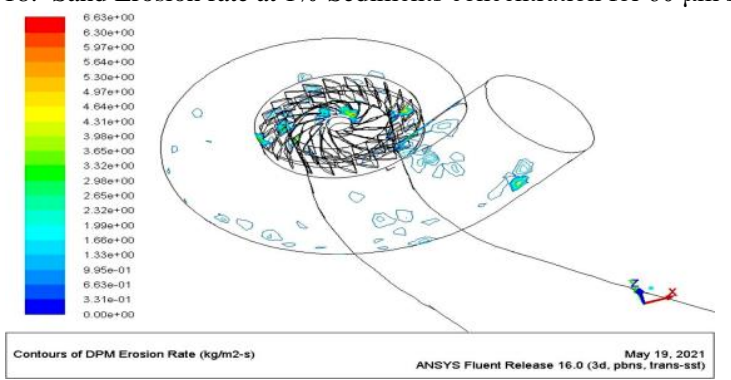

Fig. 19: Sand Erosion rate at $1 \%$ Sediments concentration for $70 \mu \mathrm{m}$ size 


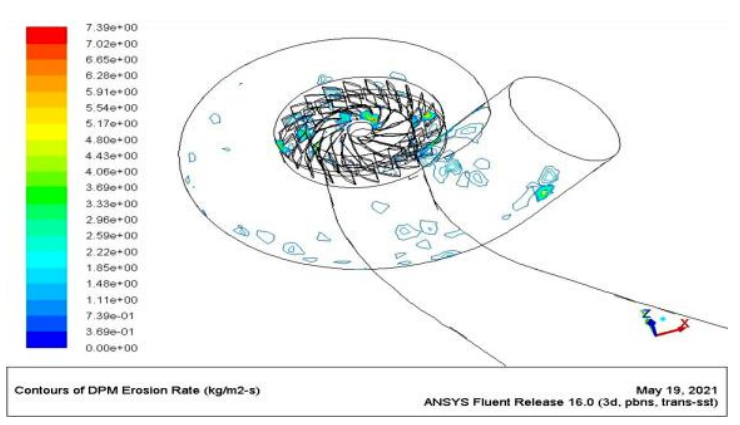

Fig. 20: Sand Erosion rate at $1 \%$ Sediments concentration for $80 \mu \mathrm{m}$ size

It has been observed that as the particle diameter increases, the penetration rate first decreases then increases, with the minimum value occurring at $30 \mu \mathrm{m}$ particle size. Thus, $30 \mu \mathrm{m}$ is the optimum size of sand for the erosion. Figure 5.3 shows that the penetration rate of $3.87 \mathrm{~kg} / \mathrm{m}^{2} \mathrm{~s}$ at $10 \mu \mathrm{m}$ particle size is even higher than that of $20 \mu \mathrm{m}$ particle size. The reason for this phenomenon may be that the dominant force for the particles with different diameter is changed. The erosion rate observed due to $1 \%$ sand concentration are $3.87,3.43,2.94$, $3.7,4.73,5.86,6.63 \& 7.39 \mathrm{Kg} / \mathrm{m}^{2} \mathrm{~s}$.

It has been observed from above fig. 21(a) that as the particle diameter increases, the penetration rate first decreases then increases, with the minimum value of $2.94 \mathrm{~kg} / \mathrm{m}^{2}$ s occurring at $30 \mu \mathrm{m}$ particle size that indicates the optimum size of sand for the erosion. Maximum erosion rate of $7.39 \mathrm{~kg} / \mathrm{m}^{2} \mathrm{~s}$ have been observed at $80 \mu \mathrm{m}$ particles size. The average erosion density rate ranging between $7.20 \mathrm{E}-02 \mathrm{~kg} / \mathrm{h}-\mathrm{m}^{2}$ at $10 \mu \mathrm{m}$ to $1.48 \mathrm{E}-01$ $\mathrm{kg} / \mathrm{h}-\mathrm{m}^{2}$ at $80 \mu \mathrm{m}$ as shown in 21(b).

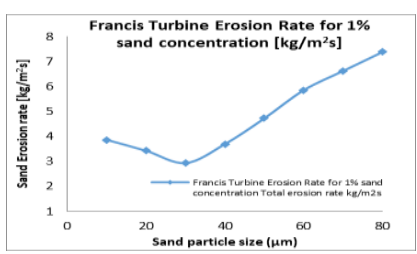

Fig. 21 (a): Erosion rate for $1 \%$ sand concentration

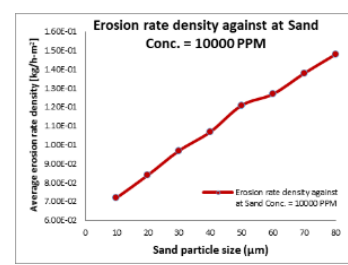

Fig. 21 (b): Average erosion rate density for $1 \%$ sand concentration
Sand Erosion rate analysis at 20000 PPM sediments concentration:

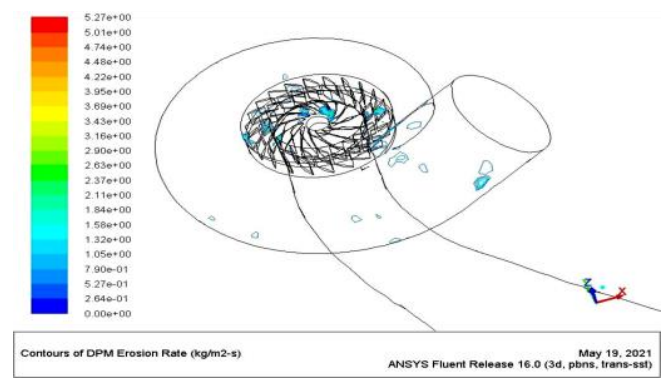

Fig. 22: Sand Erosion rate at 2\% Sediments concentration for $10 \mu \mathrm{m}$ size

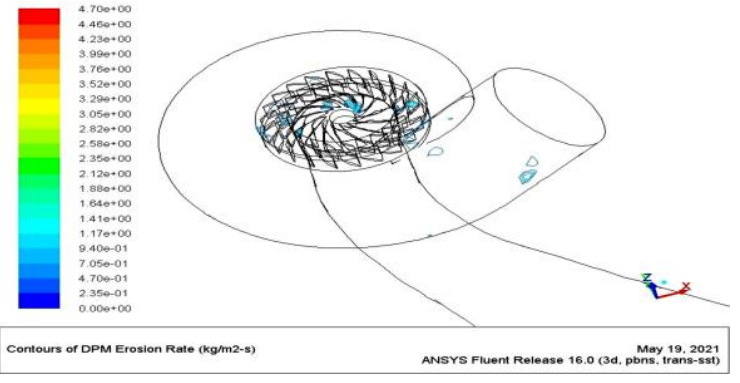

Fig. 23: Sand Erosion rate at 2\% Sediments concentration for $20 \mu \mathrm{m}$ size

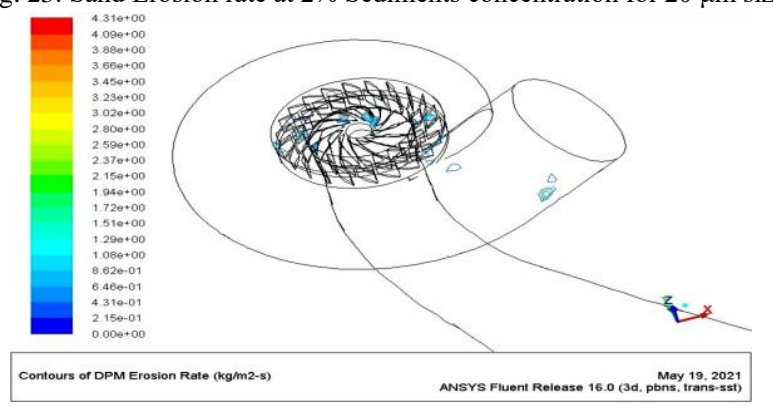

Fig. 24: Sand Erosion rate at 2\% Sediments concentration for $30 \mu \mathrm{m}$ size

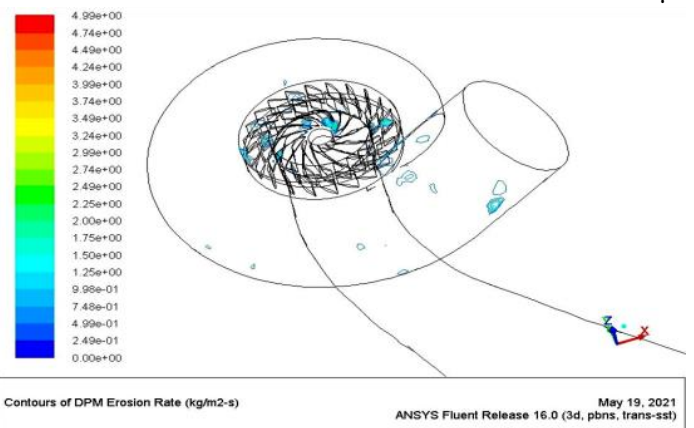

Fig. 25: Erosion rate at $2 \%$ Sediments concentration for $40 \mu \mathrm{m}$ size

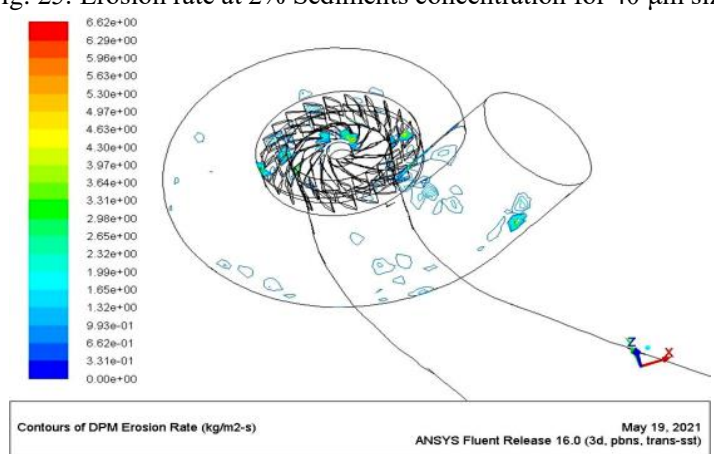

Fig. 26: Sand Erosion rate at 2\% Sediments concentration for $50 \mu \mathrm{m}$ size

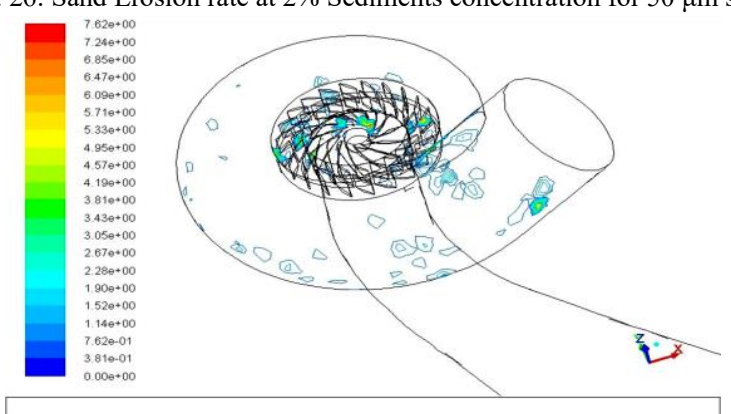

ANSYS Fluent Release 16.0 (3d, pbns, trans-ssit)

Fig. 27: Erosion rate at $2 \%$ Sediments concentration for $60 \mu \mathrm{m}$ size 


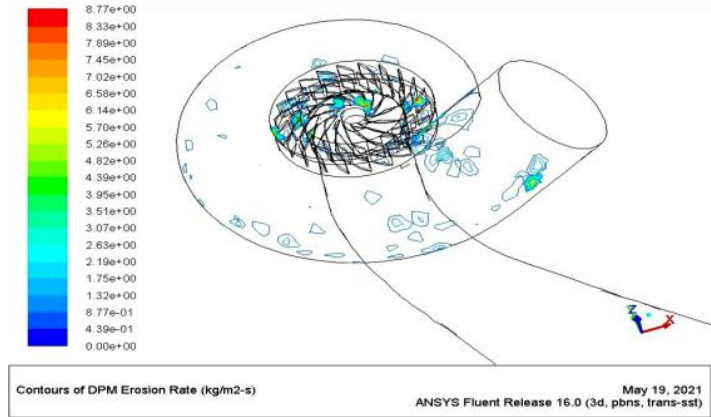

Fig. 28: Erosion rate at 2\% Sediments concentration for $70 \mu \mathrm{m}$ size

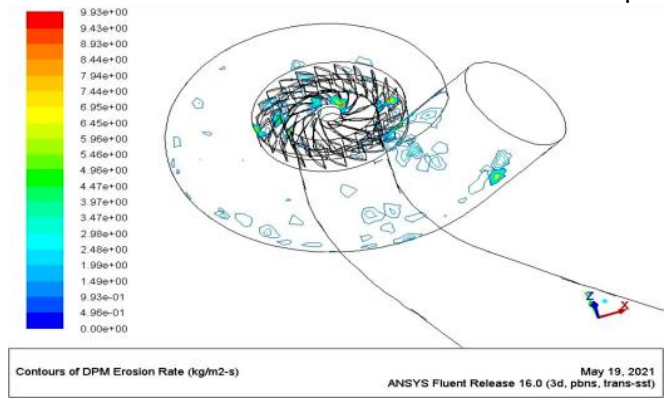

Fig. 29: Sand Erosion rate at 2\% Sediments concentration for $80 \mu \mathrm{m}$ size It has been observed that as the particle diameter increases, the penetration rate first decreases then increases, with the minimum value occurring at $30 \mu \mathrm{m}$ particle size. Thus, $30 \mu \mathrm{m}$ is the optimum size of sand for the erosion. fig. 29 shows that the penetration rate of $5.27 \mathrm{~kg} / \mathrm{m}^{2} \mathrm{~s}$ at $10 \mu \mathrm{m}$ particle size is even higher than that of $20 \mu \mathrm{m}$ particle size.. The erosion rate observed due to $2 \%$ sand concentration are $5.27,4.70,4.31$, $4.99,6.62,7.616,8.77 \& 9.926 \mathrm{Kg} / \mathrm{m}^{2} \mathrm{~s}$.

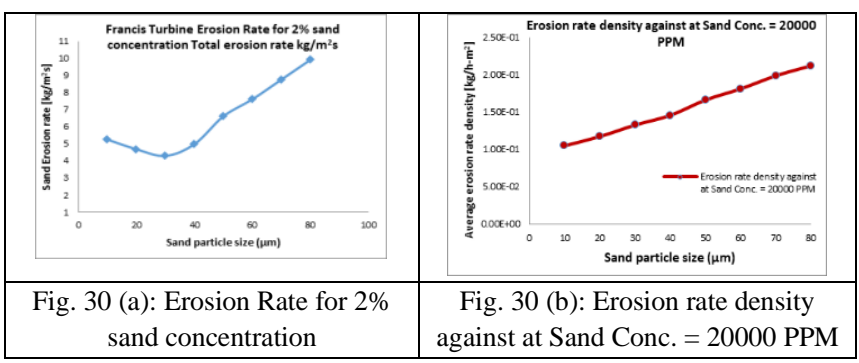

It has been observed from above fig. 30 (a) that as the particle diameter increases, the penetration rate first decreases then increases, with the minimum value of $4.31 \mathrm{~kg} / \mathrm{m}^{2} \mathrm{~s}$ occurring at $30 \mu \mathrm{m}$ particle size that indicates the optimum size of sand for the erosion. Maximum erosion rate of $9.926 \mathrm{~kg} / \mathrm{m}^{2} \mathrm{~s}$ have been observed at $80 \mu \mathrm{m}$ particles size. The average erosion density rate ranging between $1.05 \mathrm{E}-01 \mathrm{~kg} / \mathrm{h}-\mathrm{m}^{2}$ at $10 \mu \mathrm{m}$ to $2.12 \mathrm{E}-01$ $\mathrm{kg} / \mathrm{h}-\mathrm{m}^{2}$ at $80 \mu \mathrm{m}$ as shown in 30(b).

Sand Erosion rate analysis at 30000 PPM sediments concentration:

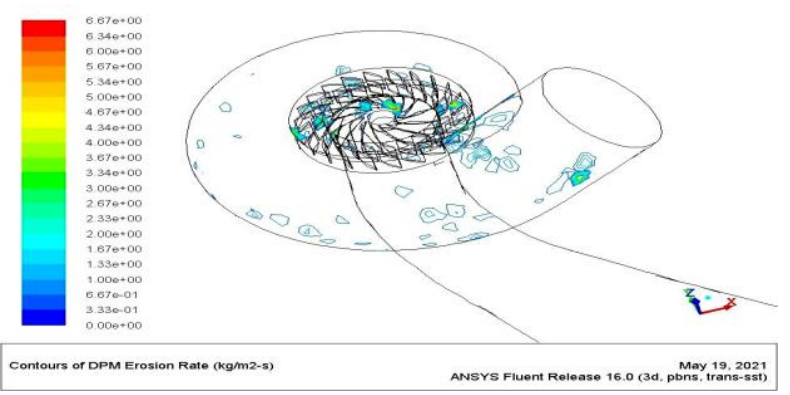

Fig. 31: Sand Erosion rate at 3\% Sediments concentration for $10 \mu \mathrm{m}$ size

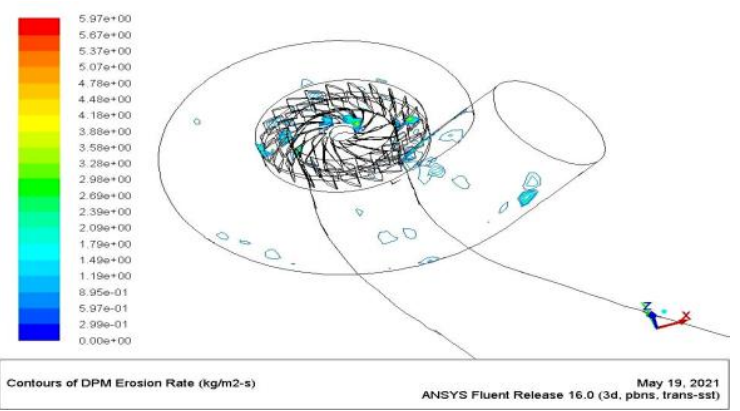

Fig. 32: Sand Erosion rate at 3\% Sediments concentration for $20 \mu \mathrm{m}$ size

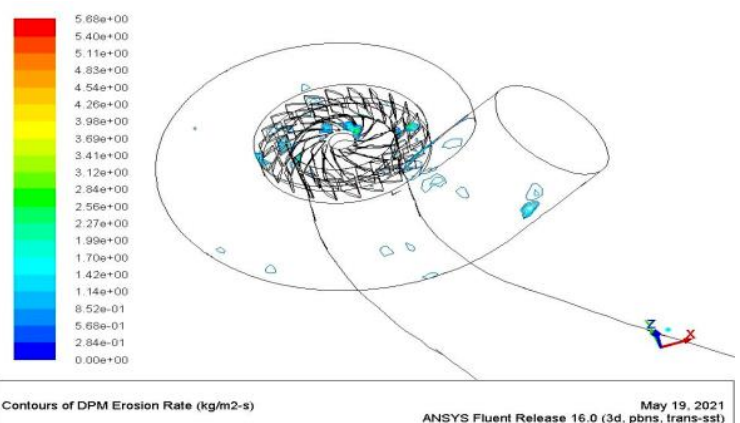

Fig. 33: Sand Erosion rate at 3\% Sediments concentration for $30 \mu \mathrm{m}$ size

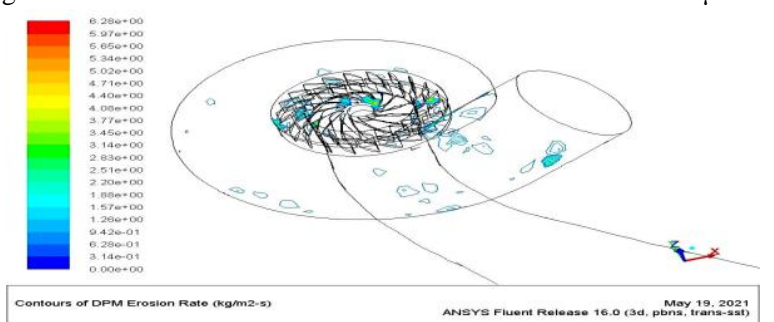

Fig. 34: Sand Erosion rate at 3\% Sediments concentration for $40 \mu \mathrm{m}$ size

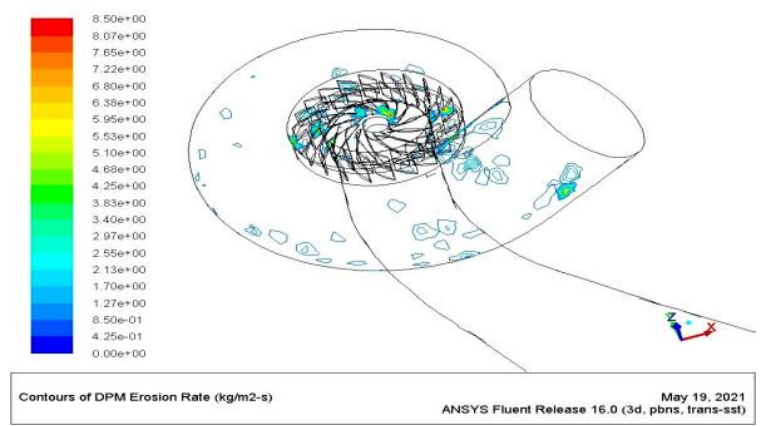

Fig. 35: Sand Erosion rate at 3\% Sediments concentration for $50 \mu \mathrm{m}$ size 


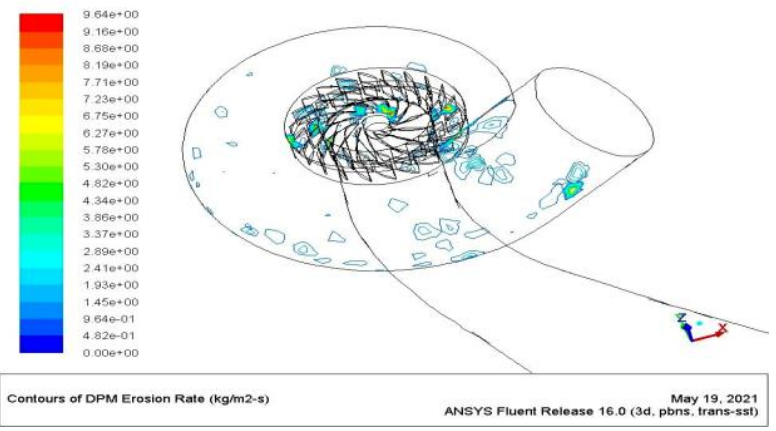

Fig. 36: Sand Erosion rate at 3\% Sediments concentration for $60 \mu \mathrm{m}$ size

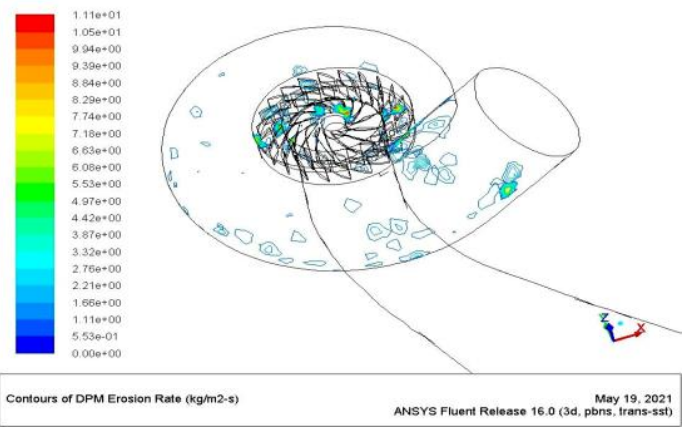

Fig. 37: Sand Erosion rate at 3\% Sediments concentration for $70 \mu \mathrm{m}$ size

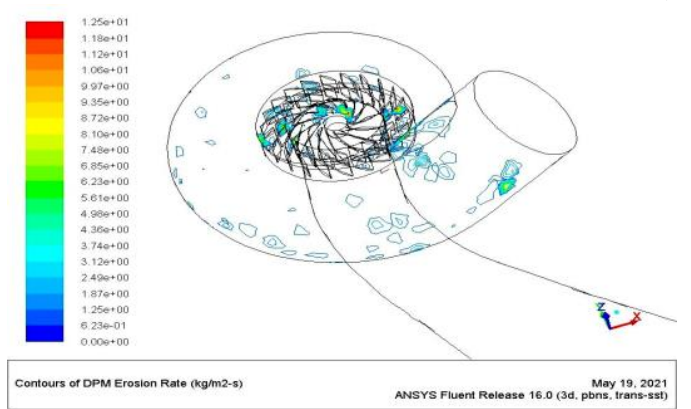

Fig. 38: Sand Erosion rate at 3\% Sediments concentration for $80 \mu \mathrm{m}$ size It has been observed that as the particle diameter increases, the penetration rate first decreases then increases, with the minimum value occurring at $30 \mu \mathrm{m}$ particle size. Thus, $30 \mu \mathrm{m}$ is the optimum size of sand for the erosion. fig. 38 shows that the penetration rate of $5.27 \mathrm{~kg} / \mathrm{m}^{2} \mathrm{~s}$ at $10 \mu \mathrm{m}$ particle size is even higher than that of $20 \mu \mathrm{m}$ particle size. The erosion rate observed due to $3 \%$ sand concentration are $6.67,5.97,5.68$, $6.28,8.5,9.64,11.05 \& 12.46 \mathrm{Kg} / \mathrm{m}^{2} \mathrm{~s}$.

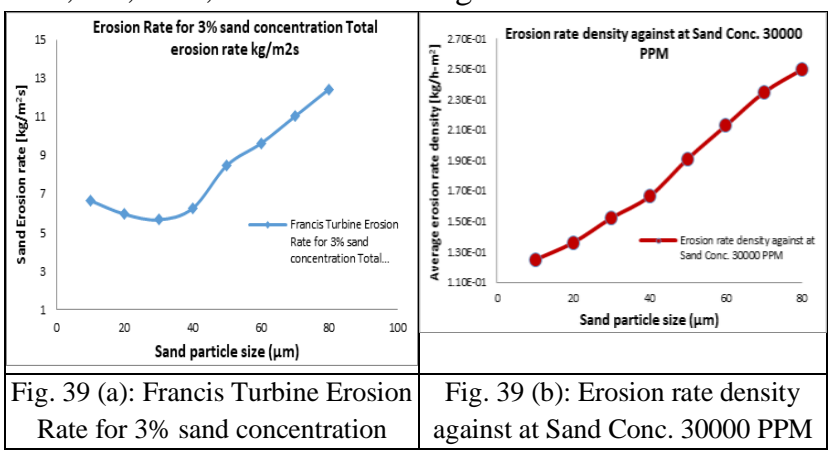

It has been observed from above figure 39 (a) that as the particle diameter increases, the penetration rate first decreases then increases, with the minimum value of $5.68 \mathrm{~kg} / \mathrm{m}^{2} \mathrm{~s}$ occurring at $30 \mu \mathrm{m}$ particle size that indicates the optimum size of sand for the erosion. Maximum erosion rate of $12.46 \mathrm{~kg} / \mathrm{m}^{2} \mathrm{~s}$ have been observed at $80 \mu \mathrm{m}$ particles size. The average erosion density rate ranging between $1.25 \mathrm{E}-01 \mathrm{~kg} / \mathrm{h}-\mathrm{m}^{2}$ at 10 $\mu \mathrm{m}$ to $2.50 \mathrm{E}-01 \mathrm{~kg} / \mathrm{h}-\mathrm{m}^{2}$ at $80 \mu \mathrm{m}$ as shown in $39(\mathrm{~b})$.

Sand Erosion rate analysis at 40000 PPM sediments concentration:

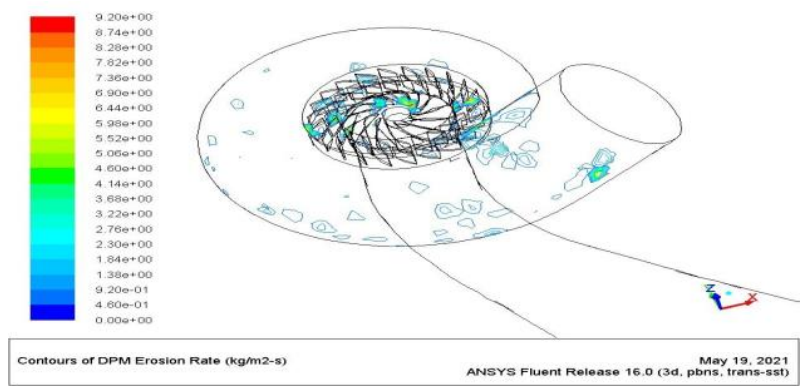

Fig. 40: Sand Erosion rate at $4 \%$ Sediments concentration for $10 \mu \mathrm{m}$ size

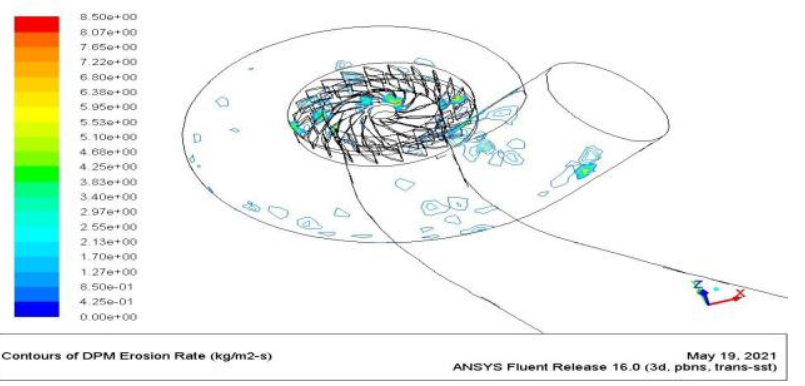

Fig. 41: Sand Erosion rate at $4 \%$ Sediments concentration for $20 \mu \mathrm{m}$ size

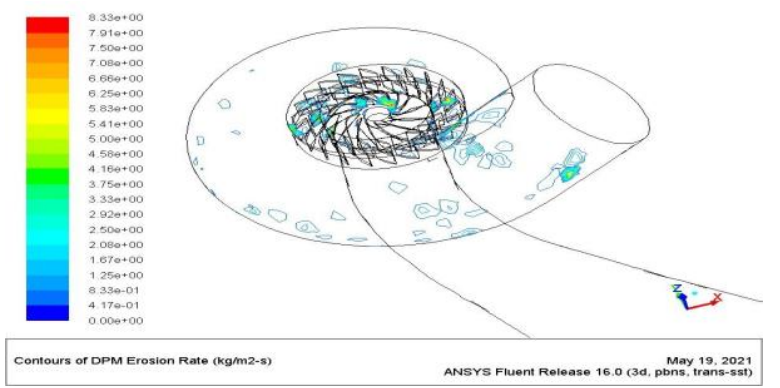

Fig. 42: Sand Erosion rate at $4 \%$ Sediments concentration for $30 \mu \mathrm{m}$ size

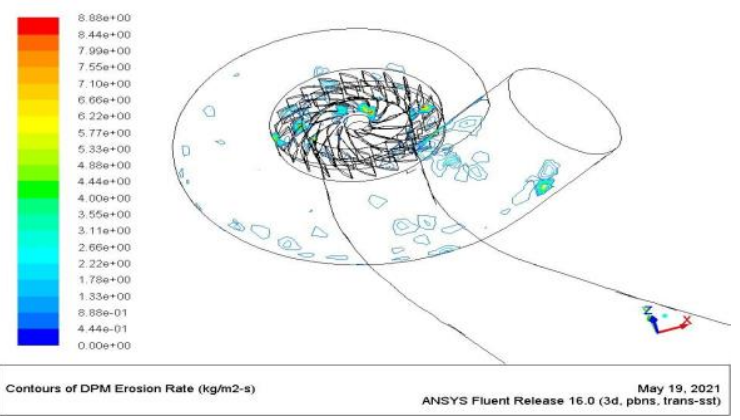

Fig. 43: Sand Erosion rate at $4 \%$ Sediments concentration for $40 \mu \mathrm{m}$ size

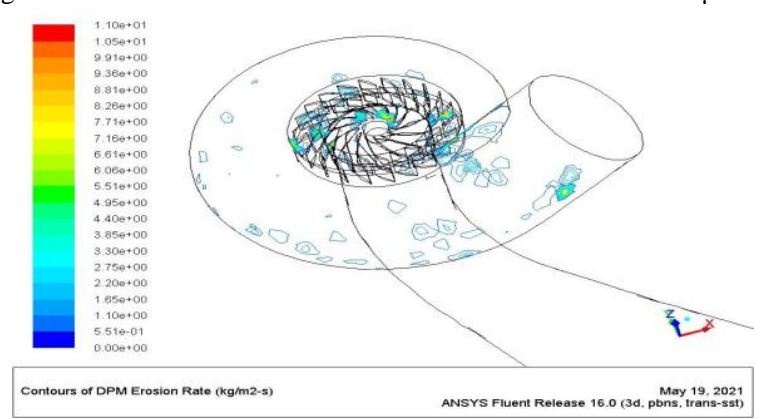


Fig. 44: Sand Erosion rate at $4 \%$ Sediments concentration for $50 \mu \mathrm{m}$ size

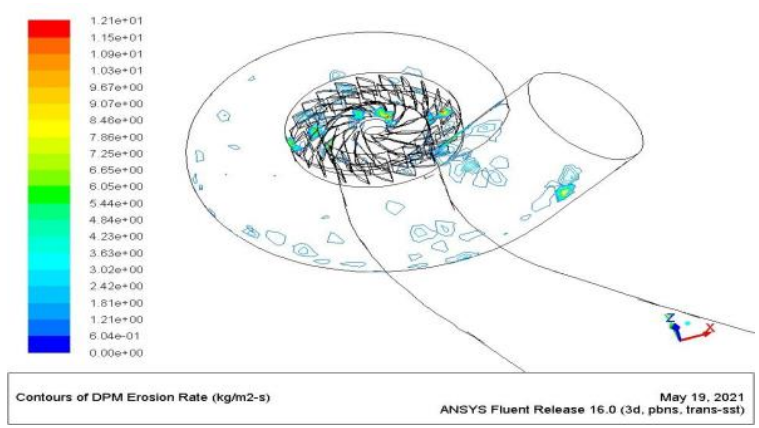

Fig. 45: Sand Erosion rate at $4 \%$ Sediments concentration for $60 \mu \mathrm{m}$ size

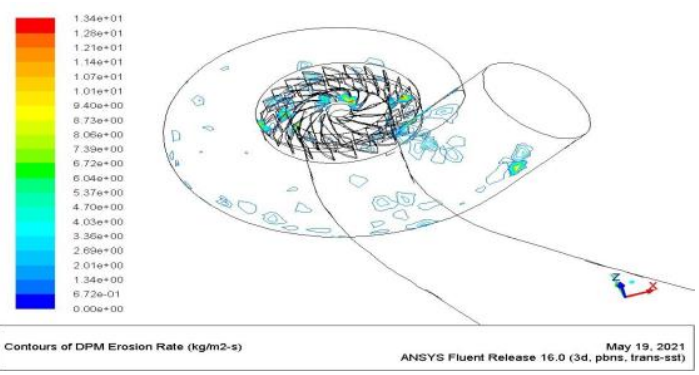

Fig. 46: Sand Erosion rate at $4 \%$ Sediments concentration for $70 \mu \mathrm{m}$ size

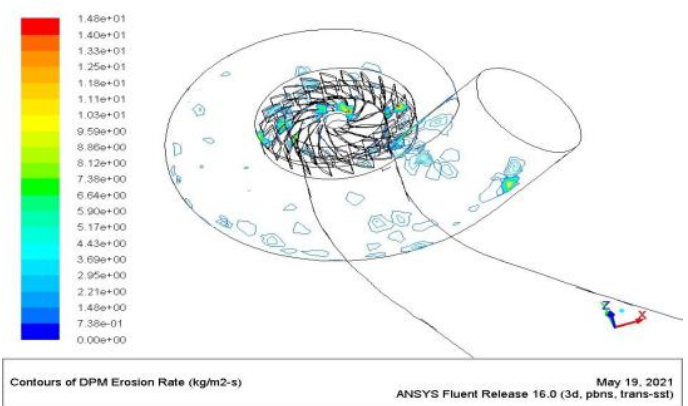

Fig. 47: Sand Erosion rate at $4 \%$ Sediments concentration for $80 \mu \mathrm{m}$ size fig. 47 shows that the penetration rate of $9.2 \mathrm{~kg} / \mathrm{m}^{2} \mathrm{~s}$ at $10 \mu \mathrm{m}$ particle size is even higher than that of $20 \mu \mathrm{m}$ particle size. The erosion rate observed due to $3 \%$ sand concentration are 9.20 , $8.5,8.33,8.88,11.01,12.09,13.43 \& 14.76 \mathrm{Kg} / \mathrm{m}^{2} \mathrm{~s}$.

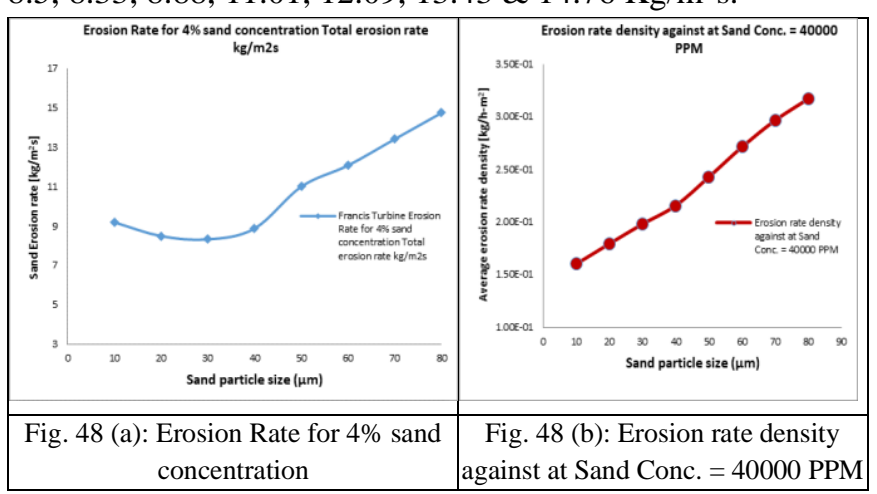

Maximum erosion rate of $14.76 \mathrm{~kg} / \mathrm{m}^{2} \mathrm{~s}$ have been observed at $80 \mu \mathrm{m}$ particles size. The average erosion density rate ranging between $1.60 \mathrm{E}-01 \mathrm{~kg} / \mathrm{h}-\mathrm{m}^{2}$ at $10 \mu \mathrm{m}$ to $3.17 \mathrm{E}-01 \mathrm{~kg} / \mathrm{h}-\mathrm{m}^{2}$ at 80 $\mu \mathrm{m}$ as shown in $48(\mathrm{~b})$.

Sand Erosion rate analysis at 50000 PPM sediments concentration:

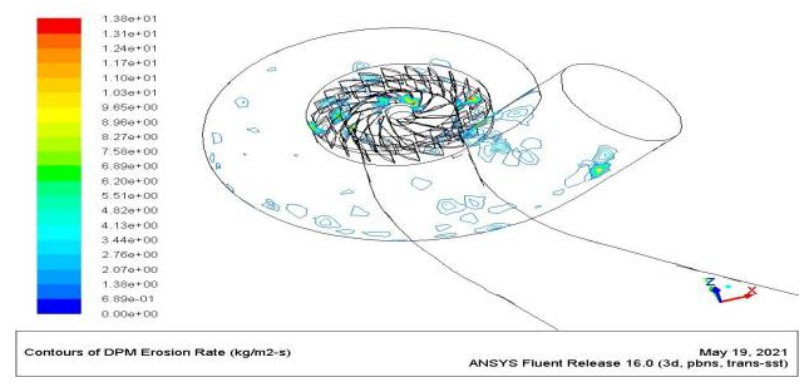

Fig. 49: Sand Erosion rate at 5\% Sediments concentration for $10 \mu \mathrm{m}$ size

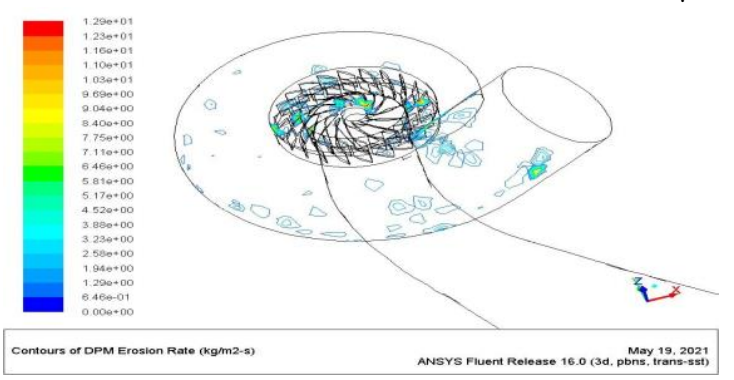

Fig. 50: Sand Erosion rate at 5\% Sediments concentration for $20 \mu \mathrm{m}$ size

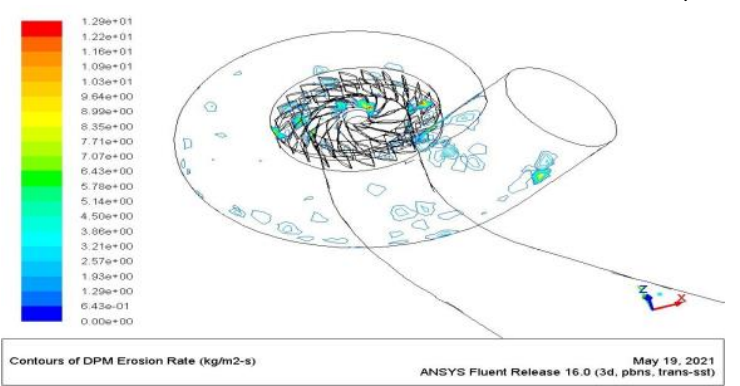

Fig. 51: Sand Erosion rate at 5\% Sediments concentration for $30 \mu \mathrm{m}$ size

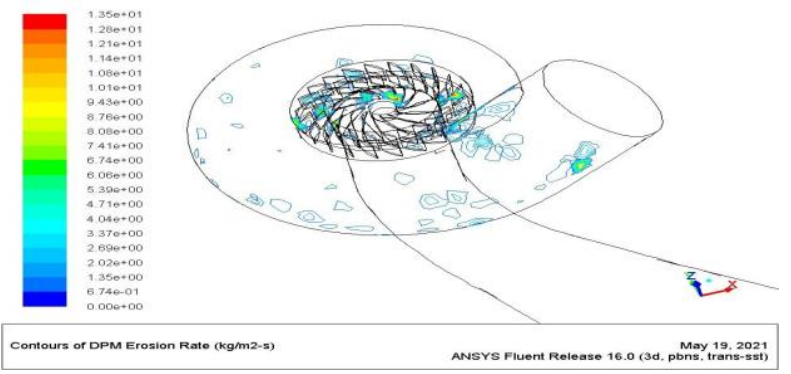

Fig. 52: Sand Erosion rate at 5\% Sediments concentration for $40 \mu \mathrm{m}$ size

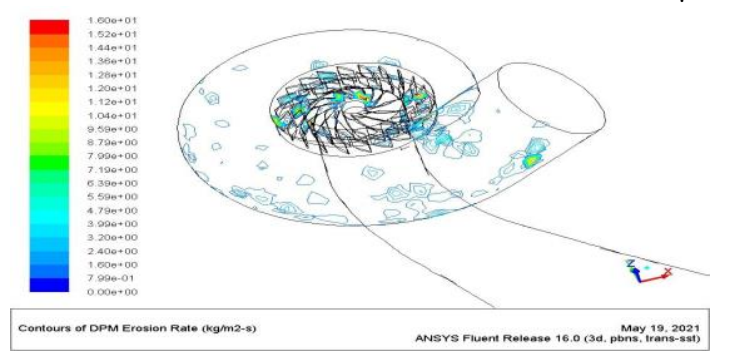

Fig. 53: Sand Erosion rate at 5\% Sediments concentration for $50 \mu \mathrm{m}$ size 


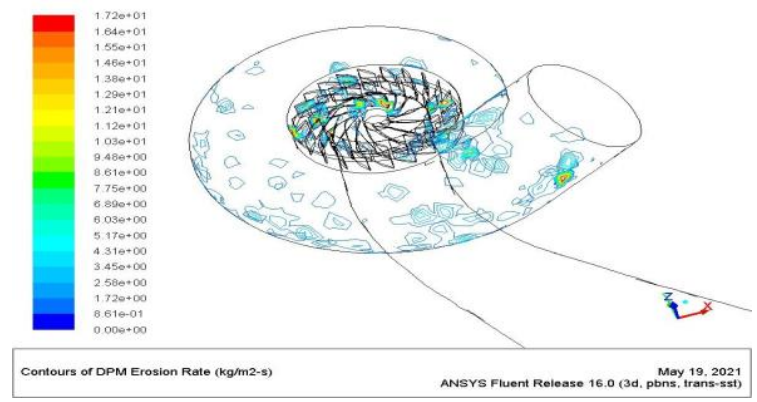

Fig. 54: Sand Erosion rate at 5\% Sediments concentration for $60 \mu \mathrm{m}$ size

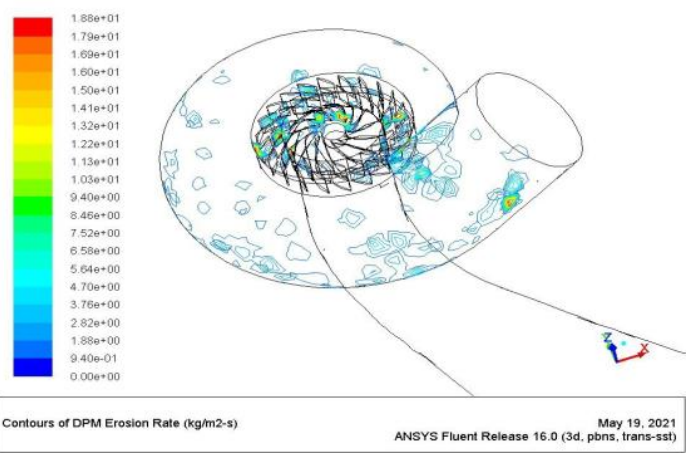

Fig. 55: Sand Erosion rate at 5\% Sediments concentration for $70 \mu \mathrm{m}$ size

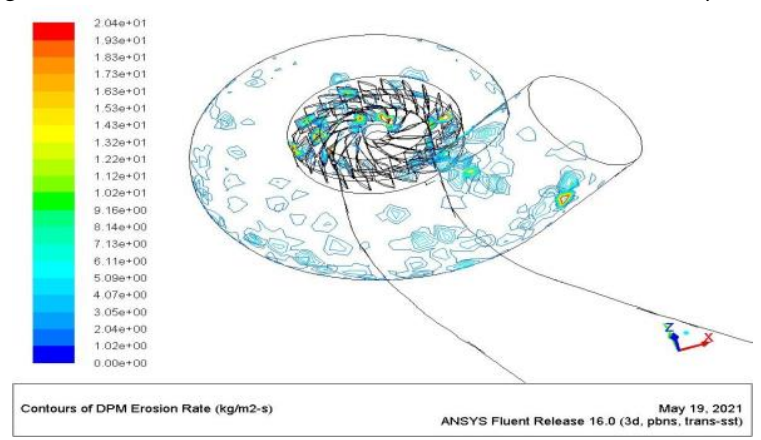

Fig. 56: Sand Erosion rate at 5\% Sediments concentration for $80 \mu \mathrm{m}$ size fig. 56 shows that the penetration rate of $13.78 \mathrm{~kg} / \mathrm{m}^{2} \mathrm{~s}$ at 10 $\mu \mathrm{m}$ particle size is even higher than that of $20 \mu \mathrm{m}$ particle size. The erosion rate observed due to $5 \%$ sand concentration are $13.78,12.92,12.85,13.47,15.98,17.23,18.795 \& 20.36$ $\mathrm{Kg} / \mathrm{m}^{2} \mathrm{~s}$.

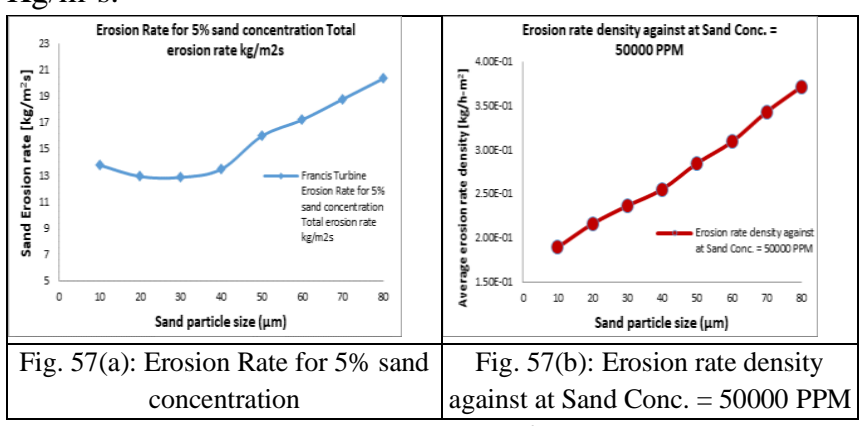

Maximum erosion rate of $20.36 \mathrm{~kg} / \mathrm{m}^{2} \mathrm{~s}$ have been observed at $80 \mu \mathrm{m}$ particles size. The average erosion density rate ranging between $1.89 \mathrm{E}-01 \mathrm{~kg} / \mathrm{h}-\mathrm{m}^{2}$ at $10 \mu \mathrm{m}$ to $3.72 \mathrm{E}-01 \mathrm{~kg} / \mathrm{h}-\mathrm{m}^{2}$ at 80 $\mu \mathrm{m}$ as shown in 57(b).

Sand Erosion rate analysis at 60000 PPM sediments concentration:

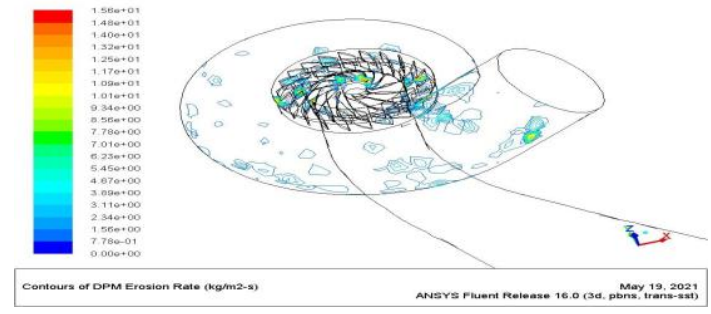

Fig. 58: Sand Erosion rate at 6\% Sediments concentration for $10 \mu \mathrm{m}$ size

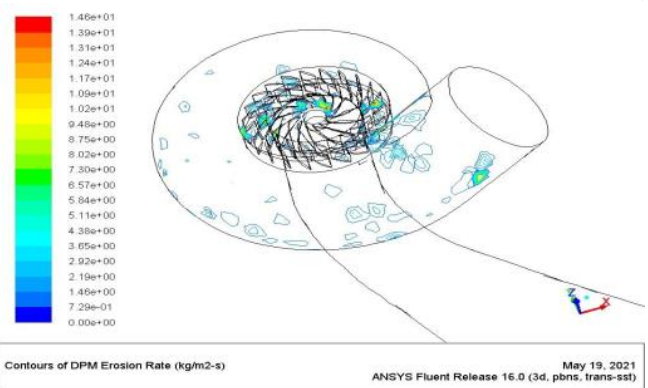

Fig. 59: Sand Erosion rate at 6\% Sediments concentration for $20 \mu \mathrm{m}$ size

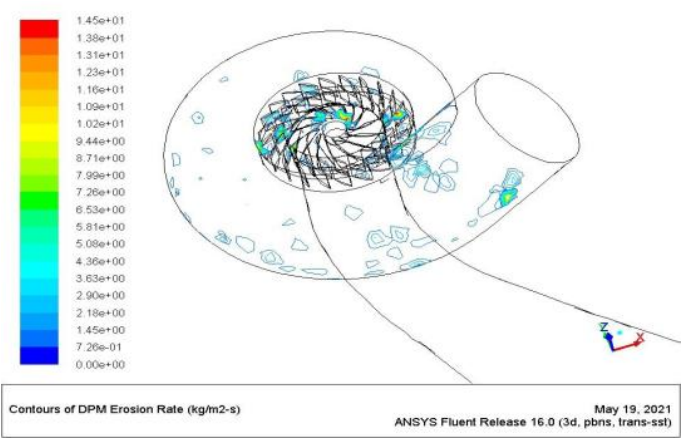

Fig. 60: Sand Erosion rate at 6\% Sediments concentration for $30 \mu \mathrm{m}$ size

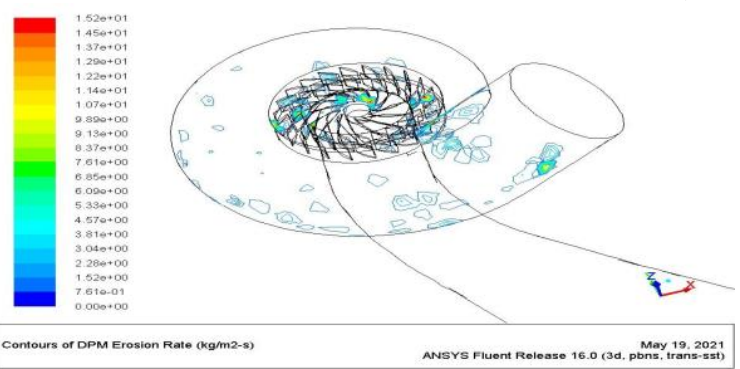

Fig. 61: Sand Erosion rate at 6\% Sediments concentration for $40 \mu \mathrm{m}$ size

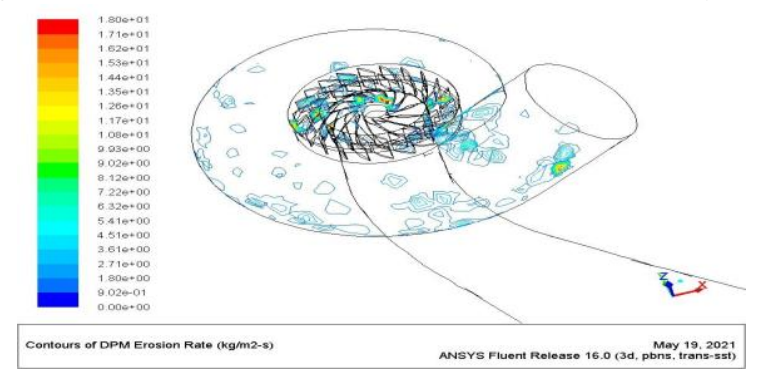

Fig. 62: Sand Erosion rate at 6\% Sediments concentration for $50 \mu \mathrm{m}$ size 


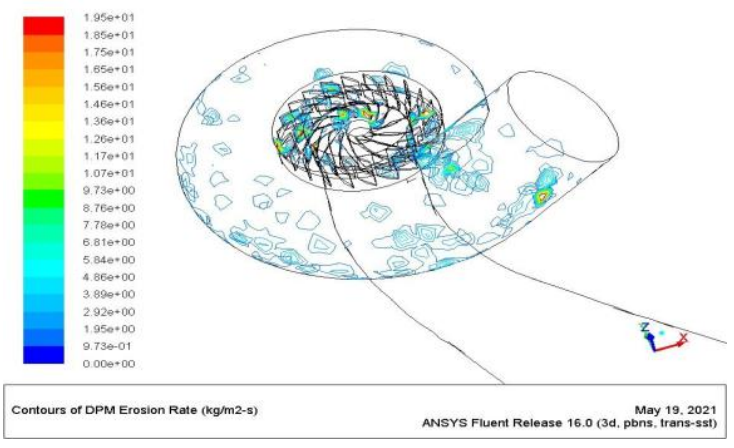

Fig. 63: Sand Erosion rate at 6\% Sediments concentration for $60 \mu \mathrm{m}$ size

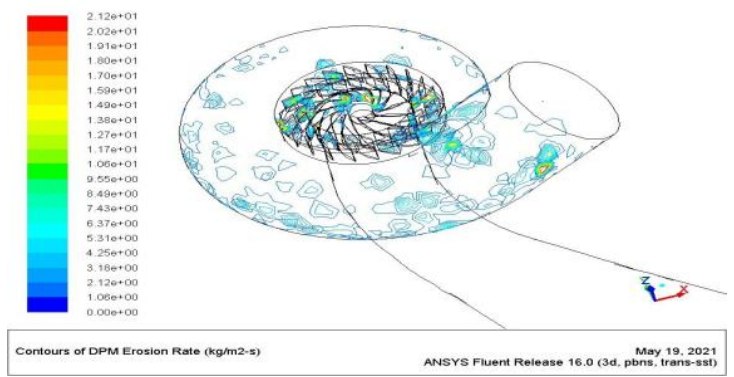

Fig. 64: Sand Erosion rate at 6\% Sediments concentration for $70 \mu \mathrm{m}$ size

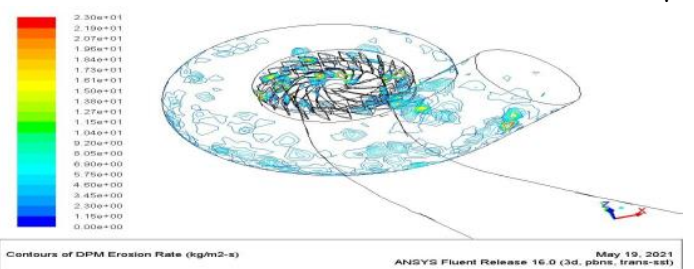

Fig. 65: Sand Erosion rate at 6\% Sediments concentration for $80 \mu \mathrm{m}$ size It has been observed that as the particle diameter increases, the penetration rate first decreases then increases, with the minimum value occurring at $30 \mu \mathrm{m}$ particle size. Thus, $30 \mu \mathrm{m}$ is the optimum size of sand for the erosion. figure 65 shows that the penetration rate of $15.57 \mathrm{~kg} / \mathrm{m}^{2} \mathrm{~s}$ at $10 \mu \mathrm{m}$ particle size is even higher than that of $20 \mu \mathrm{m}$ particle size. The erosion rate observed due to $6 \%$ sand concentration are $15.57,14.59$, $14.52,15.22,18.05,19.46,21.23 \& 23.01 \mathrm{Kg} / \mathrm{m}^{2} \mathrm{~s}$.

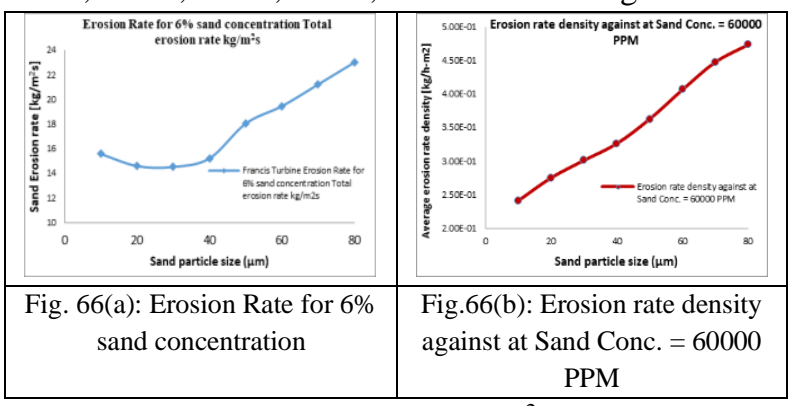

Maximum erosion rate of $23.01 \mathrm{~kg} / \mathrm{m}^{2}$ s have been observed at $80 \mu \mathrm{m}$ particles size. The average erosion density rate ranging between $2.41 \mathrm{E}-01 \mathrm{~kg} / \mathrm{h}-\mathrm{m}^{2}$ at $10 \mu \mathrm{m}$ to $4.74 \mathrm{E}-01 \mathrm{~kg} / \mathrm{h}-\mathrm{m}^{2}$ at 80 $\mu \mathrm{m}$ as shown in 5.56(b).

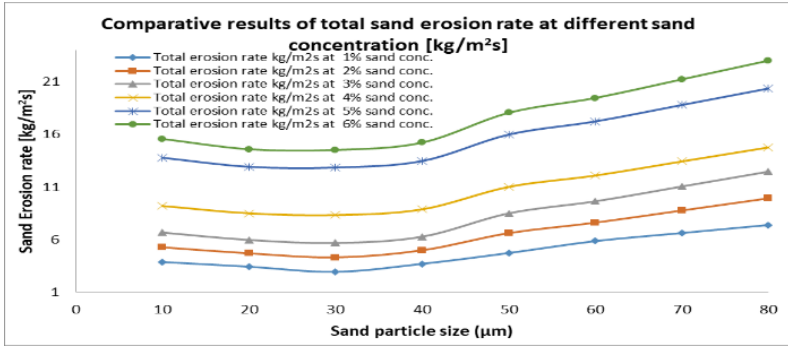

Fig. 67: Comparative results of sand erosion rate at different sand concentration

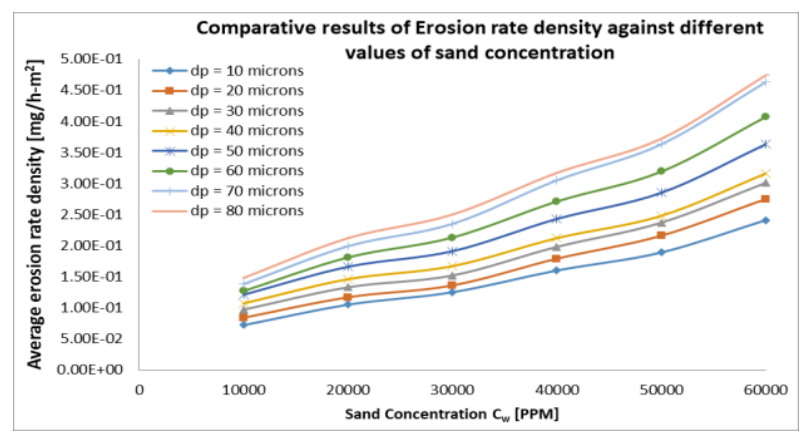

Fig. 68: Comparative results of erosion rate density against different values of sand concentration

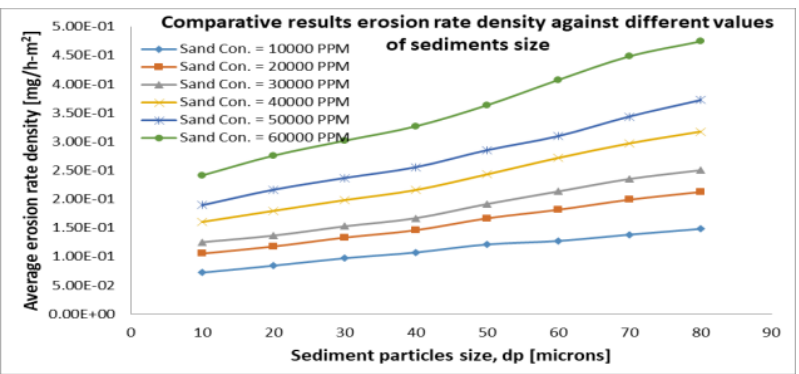

Fig. 69: Comparative results of Erosion rate density against different values of sediments size

\section{CONCLUSION}

In present work Computational fluid dynamics analysis based erosion wear prediction is performed for Francis turbine components, especially the runner. For the geometrical parameters, Francis turbine model with steady state condition and viscous flow turbulence SST model using ANSYS Fluent. For that detailed analysis in a Francis turbine casing, runner and draft tube due to the flow of sand particles has been studied for turbulent flow as transient SST model at mass flow rate where outlet of draft tube atmospheric pressure is taken as outlet boundary condition. The erosion effect on all the three component (spiral casing, runner \& draft tube) has been studied for different concentration of sand particles-1\%, $2 \%$, $3 \%, 4 \%, 5 \%$ and $6 \%$. For each of those concentration the effect of variation in size has been studied for different sizes $(10,20,30,40,50,60,70 \& 80 \mu \mathrm{m})$. Further the effect of total erosion was also analyzed for different particle size. Based on the results of the study following conclusions were drawn. 
* After performing sand erosion rate analysis for the Francis turbine at sand concentration rate $1 \%$. It has been observed that as the particle diameter increases, the penetration rate first decreases then increases, with the minimum value occurring at $30 \mu \mathrm{m}$ particle size. The penetration rate of $3.87 \mathrm{~kg} / \mathrm{m}^{2} \mathrm{~s}$ at $10 \mu \mathrm{m}$ particle size is even higher than that of $20 \mu \mathrm{m}$ particle size. The erosion rate observed due to $1 \%$ sand concentration are $3.87,3.43$, $2.94,3.7,4.73,5.86,6.63 \& 7.39 \mathrm{Kg} / \mathrm{m}^{2} \mathrm{~s}$. The average erosion density rate ranging between $7.20 \mathrm{E}-02 \mathrm{~kg} / \mathrm{h}-\mathrm{m}^{2}$ at $10 \mu \mathrm{m}$ to $1.48 \mathrm{E}-01 \mathrm{~kg} / \mathrm{h}-\mathrm{m}^{2}$ at $80 \mu \mathrm{m}$.

* After performing sand erosion rate analysis for the Francis turbine at sand concentration rate $2 \%$. It has been observed that as the particle diameter increases, the penetration rate first decreases then increases, with the minimum value occurring at $30 \mu \mathrm{m}$ particle size. The penetration rate of $5.27 \mathrm{~kg} / \mathrm{m}^{2} \mathrm{~s}$ at $10 \mu \mathrm{m}$ particle size is even higher than that of $20 \mu \mathrm{m}$ particle size. The erosion rate observed due to $2 \%$ sand concentration are 5.27, 4.70, $4.31,4.99,6.62,7.616,8.77 \& 9.926 \mathrm{Kg} / \mathrm{m}^{2} \mathrm{~s}$. The average erosion density rate ranging between $1.05 \mathrm{E}-01 \mathrm{~kg} / \mathrm{h}-\mathrm{m}^{2}$ at $10 \mu \mathrm{m}$ to $2.12 \mathrm{E}-01 \mathrm{~kg} / \mathrm{h}-\mathrm{m}^{2}$ at $80 \mu \mathrm{m}$.

* After performing sand erosion rate analysis for the Francis turbine at sand concentration rate $3 \%$. It has been observed that as the particle diameter increases, the penetration rate first decreases then increases, with the minimum value occurring at $30 \mu \mathrm{m}$ particle size. The penetration rate of $5.27 \mathrm{~kg} / \mathrm{m}^{2} \mathrm{~s}$ at $10 \mu \mathrm{m}$ particle size is even higher than that of $20 \mu \mathrm{m}$ particle size. The erosion rate observed due to $3 \%$ sand concentration are 6.67 , $5.97,5.68,6.28,8.5,9.64,11.05 \& 12.46 \mathrm{Kg} / \mathrm{m}^{2} \mathrm{~s}$. The average erosion density rate ranging between $1.25 \mathrm{E}-01$ $\mathrm{kg} / \mathrm{h}-\mathrm{m}^{2}$ at $10 \mu \mathrm{m}$ to $2.50 \mathrm{E}-01 \mathrm{~kg} / \mathrm{h}-\mathrm{m}^{2}$ at $80 \mu \mathrm{m}$.

* After performing sand erosion rate analysis for the francis turbine at sand concentration rate $4 \%$ It has been observed that as the particle diameter increases, the penetration rate first decreases then increases, with the minimum value occurring at $30 \mu \mathrm{m}$ particle size. The penetration rate of $9.2 \mathrm{~kg} / \mathrm{m}^{2} \mathrm{~s}$ at $10 \mu \mathrm{m}$ particle size is even higher than that of $20 \mu \mathrm{m}$ particle size. The erosion rate observed due to $3 \%$ sand concentration are $9.20,8.5,8.33,8.88,11.01$, $12.09,13.43 \& 14.76 \mathrm{Kg} / \mathrm{m}^{2} \mathrm{~s}$. The average erosion density rate ranging between $1.60 \mathrm{E}-01 \mathrm{~kg} / \mathrm{h}-\mathrm{m}^{2}$ at $10 \mu \mathrm{m}$ to $3.17 \mathrm{E}-01 \mathrm{~kg} / \mathrm{h}-\mathrm{m}^{2}$ at $80 \mu \mathrm{m}$.

* After performing sand erosion rate analysis for the francis turbine at sand concentration rate $5 \%$. It has been observed that as the particle diameter increases, the penetration rate first decreases then increases, with the minimum value occurring at $30 \mu \mathrm{m}$ particle size. The penetration rate of $13.78 \mathrm{~kg} / \mathrm{m}^{2} \mathrm{~s}$ at $10 \mu \mathrm{m}$ particle size is even higher than that of $20 \mu \mathrm{m}$ particle size. The erosion rate observed due to $5 \%$ sand concentration are 13.78 ,
$12.92,12.85,13.47,15.98,17.23,18.795$ \& 20.36 $\mathrm{Kg} / \mathrm{m}^{2} \mathrm{~s}$. The average erosion density rate ranging between $1.89 \mathrm{E}-01 \mathrm{~kg} / \mathrm{h}-\mathrm{m}^{2}$ at $10 \mu \mathrm{m}$ to $3.72 \mathrm{E}-01 \mathrm{~kg} / \mathrm{h}-\mathrm{m}^{2}$ at $80 \mu \mathrm{m}$.

* After performing sand erosion rate analysis for the francis turbine at sand concentration rate $6 \%$ It has been observed that as the particle diameter increases, the penetration rate first decreases then increases, with the minimum value occurring at $30 \mu \mathrm{m}$ particle size. The penetration rate of $15.57 \mathrm{~kg} / \mathrm{m}^{2} \mathrm{~s}$ at $10 \mu \mathrm{m}$ particle size is even higher than that of $20 \mu \mathrm{m}$ particle size. The erosion rate observed due to $6 \%$ sand concentration are $15.57,14.59,14.52,15.22$, $18.05,19.46,21.23 \& 23.01 \mathrm{Kg} / \mathrm{m}^{2} \mathrm{~s}$. The average erosion density rate ranging between $2.41 \mathrm{E}-01 \mathrm{~kg} / \mathrm{h}-\mathrm{m}^{2}$ at $10 \mu \mathrm{m}$ to $4.74 \mathrm{E}-01 \mathrm{~kg} / \mathrm{h}-\mathrm{m}^{2}$ at $80 \mu \mathrm{m}$.

It has been observed from above conclusion that erosion rate is maximum at particle size $30 \mu \mathrm{m}$ for all six concentration (1\% to $6 \%$ ). Thus, $30 \mu \mathrm{m}$ is the optimum size of sand particles for the erosion. Erosion damage is found close to the upper and lower portions of the leading edge of the stay vane. some erosion spots at guide vane on the blade pressure side where suction side has minimum erosion. Maximum erosion damage observed on runner especially at the middle of the blade. This is due to the blade profile-tail vortex flow which leads to higher erosion rate density in the blade outlet. The draft tube situated closer to runner having highest velocity due to high absolute velocity of water coming out from the runner which causes sediment erosion and generally does not produce any serious erosion effect in draft tube.

\section{References}

[1] R.D. Aponte et al. "Minimizing erosive wear through a CFD multiobjective optimization methodology for different operating points of a Francis turbine" Renewable Energy 145 (2020) $2217 \mathrm{e} 2232$. https://doi.org/10.1016/j.renene.2019.07.116.

[2] Gyanendra Tiwari et al. "Utility of CFD in the design and performance analysis of hydraulic turbines - A review" Energy Reports 6 (2020) 2410-2429. https://doi.org/10.1016/j.egyr.2020.09.004.

[3] Gyanendra Tiwari, Jitendra Kumar, Vishnu Prasad \& Vivek Kumar Patel "Derivation of cavitation characteristics of a 3MW prototype Francis turbine through numerical hydrodynamic analysis" Materials Today: Proceedings $26 \quad$ (2020) 1439-1448. https://doi.org/10.1016/j.matpr.2020.02.297.

[4] S. Gautam, H.P. Neopane, N. Acharya, S. Chitrakar, B.S. Thapa, B. $\mathrm{Zhu}$, "Sediment erosion in low specific speed francis turbines: A case study on effects and causes", Wear (2020), doi:https://doi.org/10.1016/j.wear.2019.203152.

[5] Atmaram Kayastha Thapa, B. S., Thapa, B., \& Lee, Y. H. "Experimental investigation for R\&D in sediment laden pico hydraulic francis turbine" Renewable Energy 155 (2020) 889- 898. https://doi.org/10.1016/j.renene.2020.03.116.

[6] Di Zhu, Ran Tao, Ruofu Xiao \& Litan Pan "Solving the runner blade crack problem for a Francis hydro-turbine operating under conditioncomplexity" Renewable Energy $149 \quad$ (2020) $298 \mathrm{e} 320$. https://doi.org/10.1016/j.renene.2019.12.057.

[7] Ravi Koirala, Hari Prasad Neopane, Baoshan Zhu \& Bhola Thapa Effect of "sediment erosion on flow around guide vanes of Francis turbine" Renewable Energy $136 \quad$ (2019) $1022 \mathrm{e} 1027$. https://doi.org/10.1016/j.renene.2019.01.045. 
[8] S. Chitrakar, H.P. Neopane, O.G. Dahlhaug, Development of a test rig for investigating the flow field around guide vanes of Francis turbines, Flow Measurement and Instrumentation, https://doi.org/10.1016/j.flowmeasinst.2019.101648.

[9] Biraj Singh Thapa, Ole Gunnar Dahlhaug \& Bhola Thapa "Flow measurements around guide vanes of Francis turbine: A PIV approach"

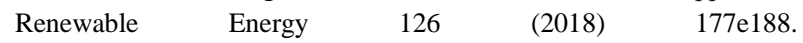
https://doi.org/10.1016/j.renene.2018.03.042.

[10] Liubomyr \& Lie, B. (2018). "Mechanistic model for Francis turbines in OpenModelica". IFAC-PapersOnLine,), IFAC PapersOnLine Volume 51, Issue 2, 2018, Pages 103108. doi:10.1016/j.ifacol.2018.03.018. 